\title{
A GIS-Agriflux Modeling and AHP Techniques for Groundwater Potential Zones Mapping
}

\author{
Nadia Trabelsi ${ }^{1}{ }^{*}$, Imen Hentati ${ }^{1}$, Ibtissem Triki ${ }^{1}$, Moncef Zairi ${ }^{1}$, Olivier Banton ${ }^{2}$ \\ ${ }^{1}$ Laboratoire Eau, Energie, Environnement, Ecole Nationale d’Ingénieurs de Sfax, Sfax, Tunisia \\ ${ }^{2}$ Laboratoire d'Hydrogéologie d'Avignon, Avignon, France \\ Email: *nadia.trabels@yahoo.fr, imenhentati@yahoo.fr, triki_ibtissem@yahoo.fr, moncef.zairi@enis.rnu.tn, \\ olivier.banton@univ-avignon.fr
}

How to cite this paper: Trabelsi, N., Hentati, I., Triki, I., Zairi, M. and Banton, O. (2022) A GIS-Agriflux Modeling and AHP Techniques for Groundwater Potential Zones Mapping. Journal of Geographic Information System, 14, 113-133. https://doi.org/10.4236/jgis.2022.142007

Received: December 29, 2021

Accepted: February 28, 2022

Published: March 3, 2022

Copyright ( 2022 by author(s) and Scientific Research Publishing Inc. This work is licensed under the Creative Commons Attribution International License (CC BY 4.0).

http://creativecommons.org/licenses/by/4.0/

\section{(c) (i) Open Access}

\begin{abstract}
Groundwater is considered as the main portion of the water supply in arid and semi-arid regions. The Sfax plain area is part of the arid/semi-arid areas of Tunisia that are subject to the impact of climatic and human pressures. Water scarcity in combination with groundwater exploitation is a major concern in this region. Therefore, sustainable management and protection of groundwater resources, it necessary. The delineation of groundwater potential (GP) zones becomes an increasingly important tool for implementing successful management programs. The purpose of the present paper is to assess the potential zone of groundwater resources in the study area. An efficient approach using geographical information system (GIS), hydrological modelling and analytical hierarchy process (AHP) was developed. At first, six groundwater parameters that affect groundwater occurrences are derived from the spatial geodatabase. Those parameters are: Infiltration rate estimated from a GIS linked model, lineament density, drainage density, slope, rainfall and Land use/land cover. Then, the assigned weights of thematic layers based on expert knowledge were normalized by eigenvector technique of AHP. The parameter layers were integrated and modeled using a weighted linear combination (WLC). The resulting map was classified into four categories: very low, low, good, and excellent. The results showed that about $26 \%$ of the study area falls under very-low-potential zone, with $30 \%$ on low-potential zone, $21 \%$ with good potential zone, and $23 \%$ falling under excellent zone. The results of the analysis were validated using pumping rate data and curve trend of sensitivity classes theory validation of outcomes indicated a good prediction accuracy. The results of the present study can serve to prepare a comprehensive groundwater development and management plans proving its efficacy in this art of exploratory investigations.
\end{abstract}




\section{Keywords}

GIS, Groundwater, Agriflux Modeling, Multi-Criteria Decision Analysis, Curve Trend of Sensitivity Classes Theory, Sfax

\section{Introduction}

Groundwater is considered one of the most valuable natural resources [1] and dependable sources of water supply in all climatic regions of all over the world [2]. In the semi-arid environment of the Sfax basin, the groundwater constitutes the main in demand, certainly with the scarity of surface water supply. During the two last decades, the region of Sfax knew an important population and economic activities increase. This development has imposed severe stress on freshwater resources available both in terms of quantity and quality. Faced with this threat of degradation and overexploitation, an assessment of this resource is extremely significant for sustainable management [3]. Description of groundwater potential (GP) zones constitutes an efficient tool in performing successful groundwater determination, protection, and management programs [4]. Sustainable groundwater potential mapping emphasizes not only locating the potential groundwater zones but also focus the optimum utilization of resources without affecting the aquifer systems [5].

Several techniques are available for hydrogeological investigations and among these approaches, the geoelectrical resistivity methods [6] [7]. The data obtained is correlated with groundwater lithological logs in the studied areas, and then were employed to generate different hydro-resistivity maps and to delineate diverse subsurface geoelectrical layers. This method shows satisfactory results in different hydrogeological settings but the main drawback of this technique remains the high material cost. Other authors combined resistivity method and hydrochemical analysis to identify the groundwater potential and problematic zones for its sustainable exploration [8]. This methodology improves knowledge about water quality and the possibilities of exploitation but the hydrochemical data are still difficult to obtain especially in large study areas and less in developing regions.

Most of These traditional approaches to groundwater exploration are expensive and time-consuming [9] [10]. In this context, modern technologies like Geographic Information System (GIS) are rather an effective, simple and reliable technique for delineating groundwater potential zones.

In recent years, (GIS) has been used for various purposes such as groundwater investigations [11] [12]. It is one of the techniques that can be used for rapid assessment of natural resources and constitute a cost-effective problem-solving platform for identifying groundwater potential zones [13]. GIS permits storing and efficient processing of georeferenced data derived and collected from various sources [14] [15] [16]. Moreover, it offers a consistent framework for ana- 
lyzing the spatial variation, allowing manipulation of geographical information [17]. This technique has been used by many researchers to prepare groundwater resources maps in many parts of the world. GIS is used to manage, classify data to explore sites, to combine the factors of groundwater recharge potential, and to provide appropriate weight relationships [18] [19] [20].

In these studies, the presence of groundwater is inferred from different surface features. The number and the nature of factors vary from one author to another. Many academics have described the interactions of the hydroclimatic, pedological and geomorphologic factors and their important role in the occurrence and distribution of groundwater [21] [22]. The most frequent parameters used in groundwater potential zoning are: geomorphology, lithology drainage density, lineament density, slope, land use, rainfall and soil [23] [24]. Moreover, a few other parameters have also been used in groundwater potential studies such as water table depth [25], water quality [26], plan curvature and distance to drainage [4] [27], aquifer transmissivity and storativity [28]. The integration of these multiple hydrological/hydrogeological data sets can earn delineating promising groundwater reservoir in an area [29]. The final result will depend essentially on the rank and weight assigned for every parameter. Some studies have used personal judgments to assign weight to different thematic layers and their features. Probabilistic frequency ratio models have been used by reference [30] [31] [32].

More sophisticated assessments have been conducted using numerical modeling, fuzzy logic (FL), frequency ratio, artificial neural network (ANN), random forest model and analytic hierarchy process analysis. The AHP method is one of the most widely used multi-criteria decision analysis (MCDA) models [33]. It is an effective method for dealing with the decision-making process framework that allows controllers to know the relationship between goals, criterias, sub-objectives and alternatives [34]. This method has largely been explored in a number of scientific applications including groundwater potential mapping for deriving criteria weights, to support decision making and identify the groundwater potential zones.

In spite of the large-scale use of phreatic groundwater in Sfax basin, few studies have been conducted in demarcating potential groundwater resources. Therefore, this study was carried out with an objective to assess the potential areas of groundwater resources based on integrated analytical hierarchy process (AHP), geographic information system (GIS) and hydrology modeling, in the Sahel of Sfax, Tunisia.

\section{Study Area}

The study focuses on the Sfax Basin in eastern part of Tunisia. This area is bounded by longitudes $9^{\circ} 33^{\prime} \mathrm{E}$ to $11^{\circ} 10^{\prime} \mathrm{E}$ and latitudes $35^{\circ} 40^{\prime} \mathrm{N}$ to $34^{\circ} 10^{\prime} \mathrm{N}$ (Figure 1). It occupies an area of about $8000 \mathrm{~km}^{2}$. It is limited in the eastern side by the Mediterranean Sea, in the west by N-S Axis mountain chain [35]. In the north by SW-NE alignment structures of Kordj, Bouthadi which represents an extension of kchem el Artsoum reliefs, since the axis NS until the cost [36] and in the 

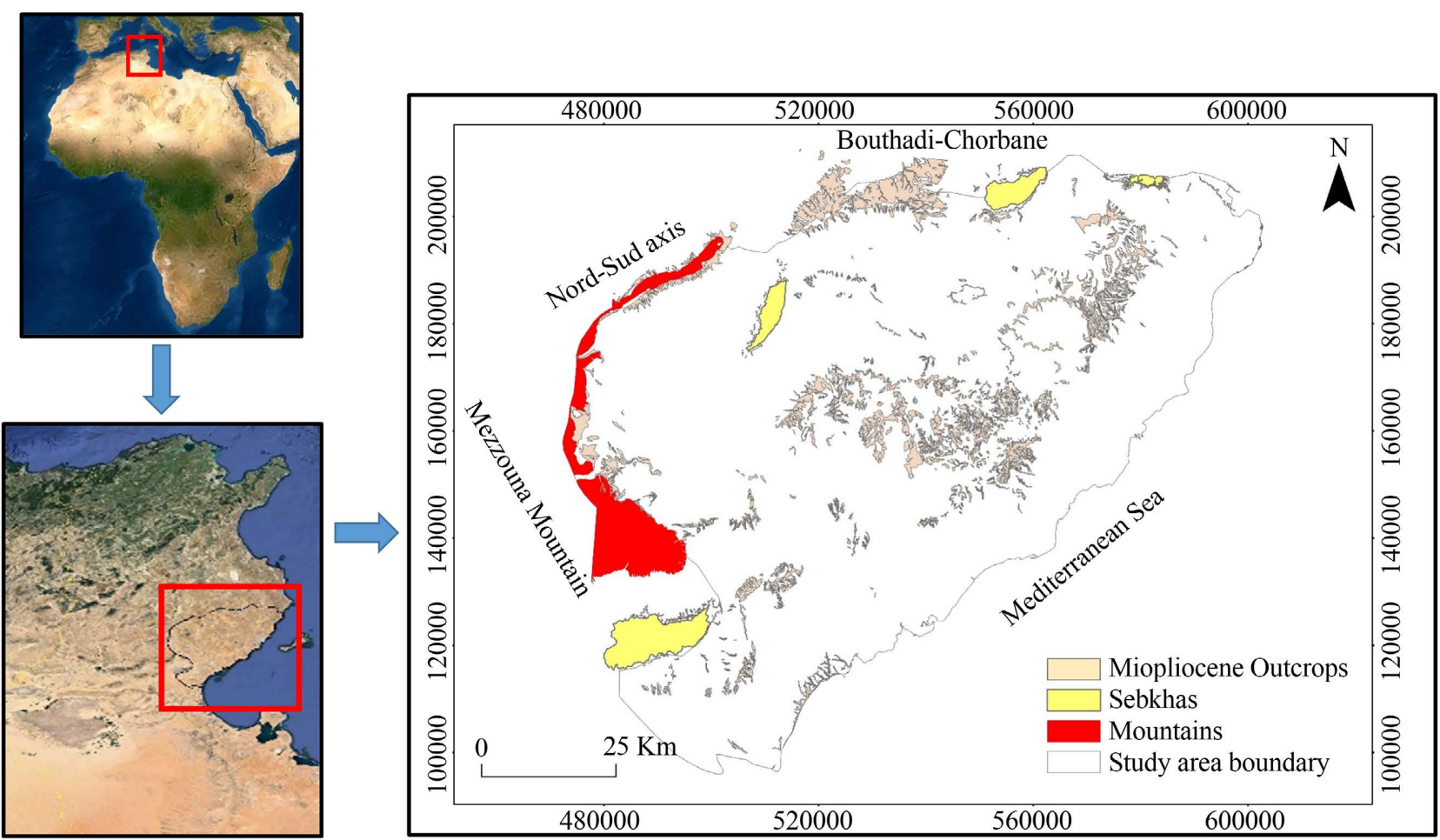

Figure 1. Location of the study area.

south by Mezzouna Mountain. The study area has an arid/semi-arid climate with annual precipitation of $230 \mathrm{~mm}$, an annual temperature of $20^{\circ} \mathrm{C}$. The surface relief is geomorphologically characterized as flat, semi-hilly in the western parts. The superficial aquifer consists of unconfined layers. The main geological material which composes the aquifer system is the sand and the silty clay of the upper Miocene, Pliocene and Quaternary.

This area has experienced rapid population growth and increased demand for phreatic groundwater reserves, which constitute the main sources of water supply. This study was initiated to explore groundwater potential areas in Sfax area.

\section{Materials and Methods}

Preparation of the groundwater potential map (GPM) using GIS involved three steps: 1) assembly of a spatial database, 2) GIS-based multi-criteria evaluation (based on Saaty's analytical hierarchy process (AHP) to compute weights for thematic layers and 3) validation of the GPM using statistics and curve trend of sensitivity classes theory (Figure 2).

\subsection{Description of Spatial Database}

The groundwater prospecting terrains requires a thorough understanding of geology, geomorphology and lineaments of an area, which is directly or indirectly controlled by the terrain characteristics like weathering grade, fracture extent, permeability, slope, drainage pattern, landforms, land use/land cover and 


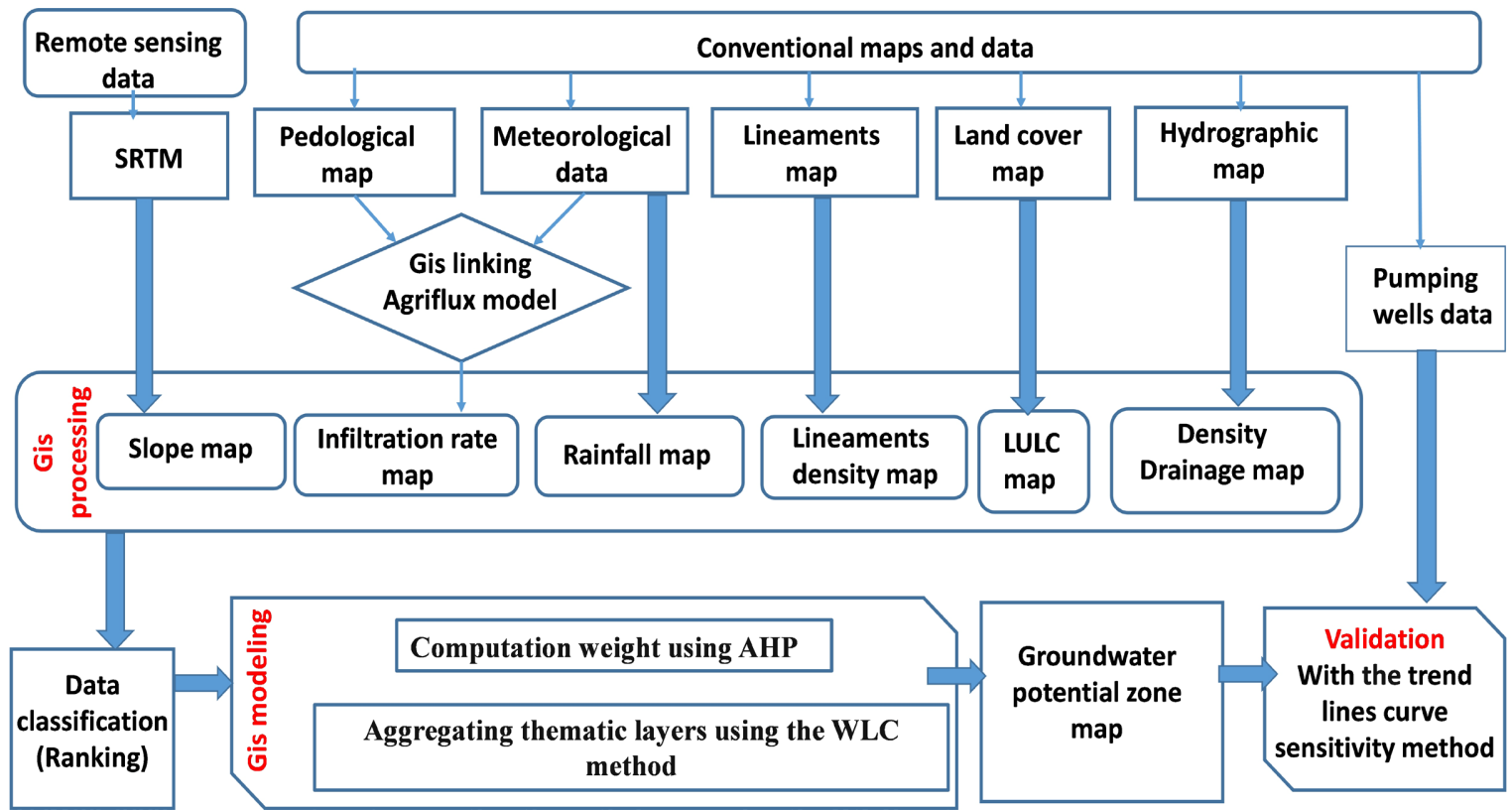

Figure 2. Flow diagram represents methodology for identification of groundwater potential zones (GWPZ).

climate [37]. The first stage to map groundwater potential is the data collection and construction of the spatial database from which the relevant factors were extracted [38]. This step is an important part of any research [39].

In this study, the modeling involves delineation the groundwater potential zones based on integration of six thematic maps in a raster based GIS. The parameters considered are: infiltration rates, lineament density, drainage density, slope, rainfall and land cover/use (LULC).

The use of Agriflux model permitted to calculate flux of infiltration. The output is transferred in a GIS environment which allows automatic subdivision of the study area into grid, flux calculations and GIS overlay computations (Figure 3).

The elevation and slope maps were prepared from SRTM data in ArcGIS environment. The hydrographic, lineaments land cover/use maps in 1:50,000 scale for the study area were collected from direction of water resources of Sfax [40]. Information of 12 weather station's annual precipitations [41] is used to generate rainfall map. The groundwater potential zones were obtained by overlaying all the thematic maps in terms of weighted overlay methods.

\subsection{GIS Modeling}

It is important to understand the control of above-mentioned factors on the groundwater regime of any area for optimal exploitation and aquifer management [14]. Many researchers have applied different types of GIS modeling techniques to assign weights of the parameters. One of the most used approach is the AHP model [42] [43] [44] [45].This study employs the AHP to assign weights of the factors and use the weighted linear combination (WLC) method to aggregate thematic layers and identify GP areas of Sfax plain. 


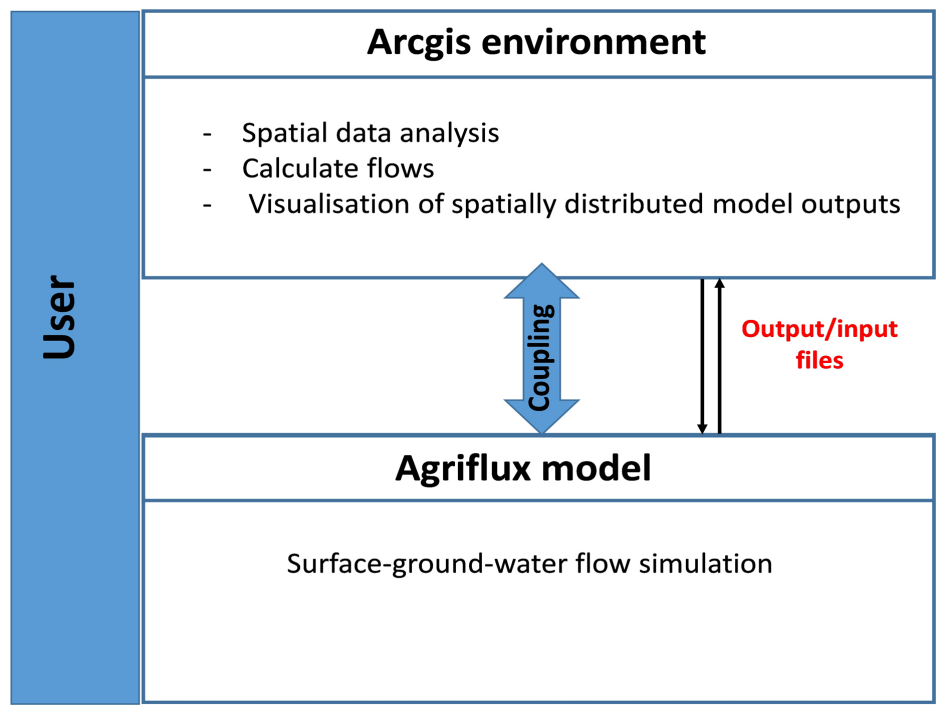

Figure 3. The coupling GIS-Agriflux Approach.

\subsubsection{Computation Weight Using AHP}

The GIS-based AHP method has been recognised by the international scientific community as a powerful tool for analyzing complex spatial decision problems [46]. It is the most widely accepted method in scaling factors weights whose entries indicate the strength with which one factor dominates over the other in relation to the relative criterion [47].

The AHP model involves three steps [48]:

- Development of judgment matrices (A) by pairwise comparison: the relative importance of thematic maps is compared to each other by pair-wise comparison matrices based on Saaty's scale from 1 to 9 .

- Calculation of relative weight W.

- Strength assessment of judgment matrix-based consistency ratio (C.R)

$$
\text { C.R }=\text { C.I/R.I }
$$

where, $\mathrm{RI}$ is the random index whose value depending on the order of the matrix, and $\mathrm{CI}$ is the consistency index evaluated as:

$$
\text { C.I }=\frac{\lambda_{\max }-n}{n-1}
$$

When, $\lambda$ is the largest eigenvalue of the matrix and $n$ is number of groundwater conditioning factors.

According to reference [49] [50], the C.R value less than 0.1 is acceptable for a specific judgment matrix. However, the authors suggest that if C.R exceeds 0.1, the set of judgments may be too inconsistent to be reliable.

\subsubsection{Aggregating Thematic Layers Using the WLC Method}

After computing the weights for the several thematic layers, the individual feature layers are reclassified into subfeatures and ranks are assigned accordingly. Finally, feature maps are integrated using a weighted linear combination approach in the GIS platform. The Groundwater potential map was constructed 
according to Formula (3):

$$
\begin{aligned}
\mathrm{GPM}= & (\mathrm{IRw} * \mathrm{IRr})+(\mathrm{LDw} * \mathrm{LDr})+(\mathrm{DDw} * \mathrm{DDr})+(\mathrm{Sw} * \mathrm{Sr}) \\
& +(\mathrm{Rw} * \mathrm{Rr})+(\mathrm{LULCw} * \mathrm{LULCr})
\end{aligned}
$$

where $\mathrm{IR}=$ infiltration rate, $\mathrm{LD}=$ lineament density, $\mathrm{DD}=$ drainage density, $\mathrm{S}=$ slope, $\mathrm{R}=$ annual rainfall, $\mathrm{LULC}=$ land use/land cover, $\mathrm{w}=$ factor weight and $\mathrm{r}$ $=$ class rating.

\subsection{Validation of the GWP Map}

Any predictive model requires validation before it can be used [51]. Therefore validation is considered to be the most important process of modeling [52]. In this context, the confirmation of the final map is based on the trend lines curve sensitivity method proposed by Jourda [53]. The method is founded on the choice of evaluation criteria. This later must obey 2 principles which are independence and compliance [53]. In this study, we used drillings discharge data. It grouped into classes and was crossed with the groundwater potential map. The percentage of each class and the sensitivity factor were calculated relatively to the total number of drillings obtained by class of criteria. Curves, expressed as a percentage by sensitivity classes according to the classes of discharges, have been dressed. For the validation, the shape of the trendlines sensitivity obtained is compared with theoretical curves trend sensitivity classes (Figure 4).

\section{Results and Discussions}

\subsection{Groundwater Potential Zoning}

In this study infiltration rate, lineament density, drainage density, slope, rainfall and land use/cover have been identified to delineate the groundwater potential zones.

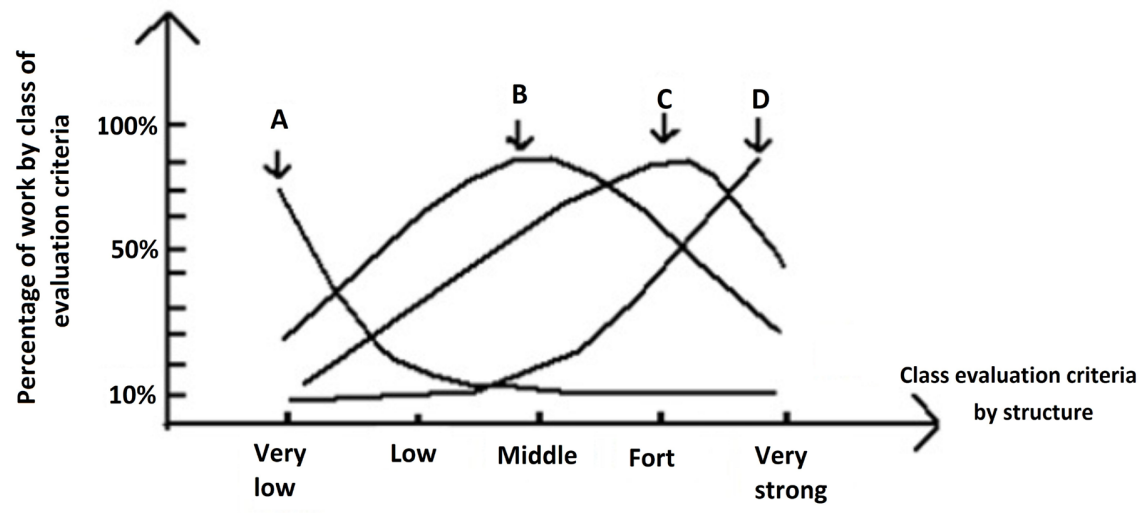
A: Bad sensitivity
B: Mediocre sensitivity
C: Good sensitivity
D: Excellent sensitivity

Figure 4. Standard curve trend of sensitivity classes according to the discharges [53]. 


\subsubsection{Infiltration Rate}

A GIS linked model approach has been adopted to specify the water infiltration rate and to quantify the effective infiltration. This is the amount of water infiltrated from the surface, which passes through the unsaturated zone and reaches the saturated zone [54] [55]. Several models respond to this problem, but our choice was to use the Agriflux model [56]. AgriFlux is a model that takes into account the spatial variability of the input parameters using their statistical distribution in a Monte Carlo approach [57]. These parameters are grouped into two principal data: 1) Climatic data and 2) hydraulic data.

Required climatic data (precipitations, temperatures and evaporation) are collected from the CRDA of Sfax. For hydraulic data, grain size distribution saturated hydraulic conductivity, residual water content, wilting point and porosity are predicted from textural data derived from the pedological map. Once we have defined the model inputs, we proceed to the Agriflux simulation of the water behavior in soil through the Hydriflux module [58].

One of the limitations of the Agriflux model, which is a one-dimensional model, is that it does not take into account the basin geometric propriety. For this reason, the integration GIS with modelling was useful. The coupling GIS-Agriflux model can help to calculate flows, visualisation of spatially distributed model outputs and establishment of infiltration map for the study area. The infiltration values varied within the range of $2 \%-18 \%$, which was classified into four classes (Figure 5(a)).

\subsubsection{Lineament Density}

Lineament analysis for groundwater exploration has considerable importance, where the joints and fractures serve as conduits for movement of groundwater and have water-holding [14] [26] [59]. Lineament density can indirectly reveal the groundwater potential and higher density area are good for groundwater potential zones [60]. This study used lineament length density, which shows the total lineament length per unit area, as shown in the following Equation (4):

$$
\operatorname{Ld}=\frac{\sum_{i=1}^{i=n} L}{A}
$$

where $\sum_{i=1}^{i=n} L=$ total length of lineaments $(\mathrm{km})$ an $A=$ area of study area $\left(\mathrm{km}^{2}\right)$.

The lineaments density map was generated in ArcGIS 10.3 using kernel density method. The resulting map, in the range of $0-2.61(\mathrm{~km} / \mathrm{km})$, was categorized into four classes. Figure 5(b) describes the drainage density criterion, classes, and their relative importance. The lineament density map of the study area reveals that high lineament density is observed in the center of the study area.

\subsubsection{The Drainage Density}

The drainage density in the area indicates a low-infiltration rate whereas the low density areas are favorable with a high-infiltration rate [61] [62].The drainage 

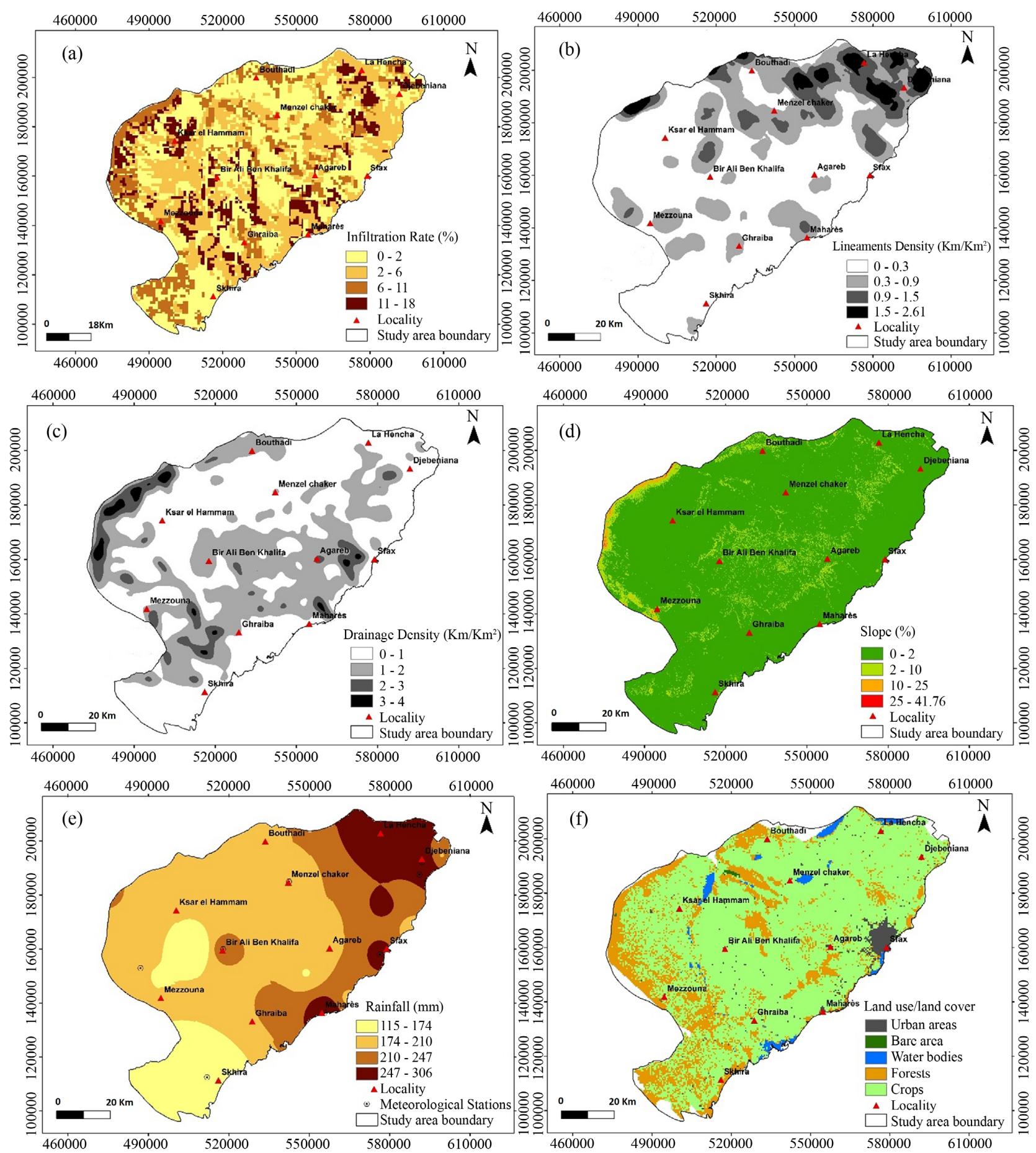

Figure 5. Thematic layers of the different factors influencing groundwater recharge potentiality: (a) IR map [59], (b): LD map; (c): DD map; (d): S map; (e): R map; (f) LULC map.

density was calculated in the same way as the lineament density, and measures the density of linear features in units of length per unit of area. The drainage density map was assigned to four classes (Figure 5(c)). It is observed that the cumulative length in the southern region is very less compared to the northern region. 


\subsubsection{Slope}

Infiltration of surface water is directly influenced by the slope gradient [10] [63]. The slope map of the study area was prepared based on SRTM data using the spatial analysis tool in ArcGis 10.3. Slope grid is identified as "the maximum rate of change in value from each cell to its neighbors" [64]. The slope map, classified into four classes determines the rate of infiltration and runoff of surface water in the study area. The flat surface areas, in the center and eastern sectors, can hold and drain the water inside of the ground, which can increase the groundwater recharge whereas the steep slopes in the western sector increase the runoff and decrease the infiltration of surface water into ground (Figure 5(d)).

\subsubsection{Rainfall}

The rainfall has a significant effect on the groundwater potential. The areas that receive more rainfall potentially have more opportunity for recharge than those with low precipitations [65]. Rainfall data of twelve meteorological stations within the study area are used [41]. The region in relation with rainfall from $115 \mathrm{~mm}$ to $306 \mathrm{~mm}$ was classified into 4 classes. It is observed that the north sector receive more rain than the rest of the study area (Figure 5(e)).

\subsubsection{Land Use/Land Cover}

The consideration of LULC factor for groundwater investigation is important because the water holding capacity of an area depends on the underlain soil types and their permeability. The LU/LC map is depicted in Figure 5(f). There are five types of land use patterns identified in the entire study area. Agriculture (74\%) and forest (21\%) are the predominant land use types in the study area. The water bodies represent $2 \%$ of the study area and interest the NW study area. The most important urban agglomeration interest the Sfax city with a $2 \%$ of the study area.

\subsection{Delineation of Groundwater Potential Zones}

Each of the six thematic layers mentioned above were reclassified (Table 1) then assigned a weight using (AHP) technique. The relative influence of the different factors, on groundwater recharge is based on expert knowledge and literature review of several researchers [17] [32]. The result of the analysis is shown in Table 2 . The consistency measure (CR) value of 0.06 shows that the judgments are highly acceptable. The results revealed that infiltration rate is the most influential parameter accounting for (40\%), lineament density at (30\%), drainage density (12\%) followed by slope, precipitation and land use.

The GWPM has been prepared using the "Equation (3)", and classified into four classes with groundwater potentiality from excellent to very poor (Figure 6). This is attributed as: $23 \%$ (excellent), $21 \%$ (good), $30 \%$ (low) and $26 \%$ (very low). Excellent and good groundwater potential zones are concentrated in the northeast and the central parts of the study area. These parts are characterized by good infiltration rate, good lineament density, low drainage density and gentle slope. The groundwater potential zone designated as low and very low are 
Table 1. Weights and ratings of the factors used to map groundwater potentiality.

\begin{tabular}{|c|c|c|}
\hline Factor & Category & Rating \\
\hline \multirow{4}{*}{ Infiltration rate (IR) (\%) } & $<2$ & 2 \\
\hline & $2-6$ & 4 \\
\hline & $6-11$ & 6 \\
\hline & $11-18$ & 8 \\
\hline \multirow{4}{*}{ Lineament density $(\mathrm{LD})\left(\mathrm{Km} / \mathrm{Km}^{2}\right)$} & $<0.3$ & 1 \\
\hline & $0.3-0.9$ & 3 \\
\hline & $0.9-1.5$ & 5 \\
\hline & $1.5-2.6$ & 7 \\
\hline \multirow{4}{*}{ drainage density (DD) $\left(\mathrm{Km} / \mathrm{Km}^{2}\right)$} & $<1$ & 8 \\
\hline & $1-2$ & 7 \\
\hline & $2-3$ & 5 \\
\hline & $3-4$ & 1 \\
\hline \multirow{4}{*}{ Slope (S) (\%) } & $<2$ & 8 \\
\hline & $2-10$ & 7 \\
\hline & $10-25$ & 3 \\
\hline & $25-42$ & 1 \\
\hline \multirow{4}{*}{ Rainfall (R) } & $115-174$ & 1 \\
\hline & $174-210$ & 3 \\
\hline & $210-247$ & 6 \\
\hline & $247-306$ & 8 \\
\hline \multirow{5}{*}{ Land use/land cover (LULC) } & Urban zones & 1 \\
\hline & Bare area & 3 \\
\hline & Water bodies & 4 \\
\hline & Forest & 6 \\
\hline & Crops & 8 \\
\hline
\end{tabular}

Table 2. Pair-wise comparison matrix for the AHP process in Sfax basin.

\begin{tabular}{cccccccc}
\hline Factor & IR & LD & DD & S & R & LULC & Weight \\
\hline Infiltration rate (IR) & 1 & 2 & 5 & 6 & 7 & 9 & $42.4 \%$ \\
Lineament density (LD) & 0.5 & 1 & 4 & 5 & 6 & 7 & $29.6 \%$ \\
drainage density (DD) & 0.2 & 0.25 & 1 & 2 & 4 & 5 & $12.2 \%$ \\
Slope (S) & 0.17 & 0.2 & 0.5 & 1 & 3 & 4 & $8.3 \%$ \\
Rainfall (R) & 0.14 & 0.17 & 0.25 & 0.33 & 1 & 3 & $4.7 \%$ \\
Land use/land cover (LULC) & 0.11 & 0.14 & 0.20 & 0.25 & 0.33 & 1 & $2.8 \%$ \\
\hline
\end{tabular}

Consistency ratio $(\mathrm{CR})=0.06<0.1$. 


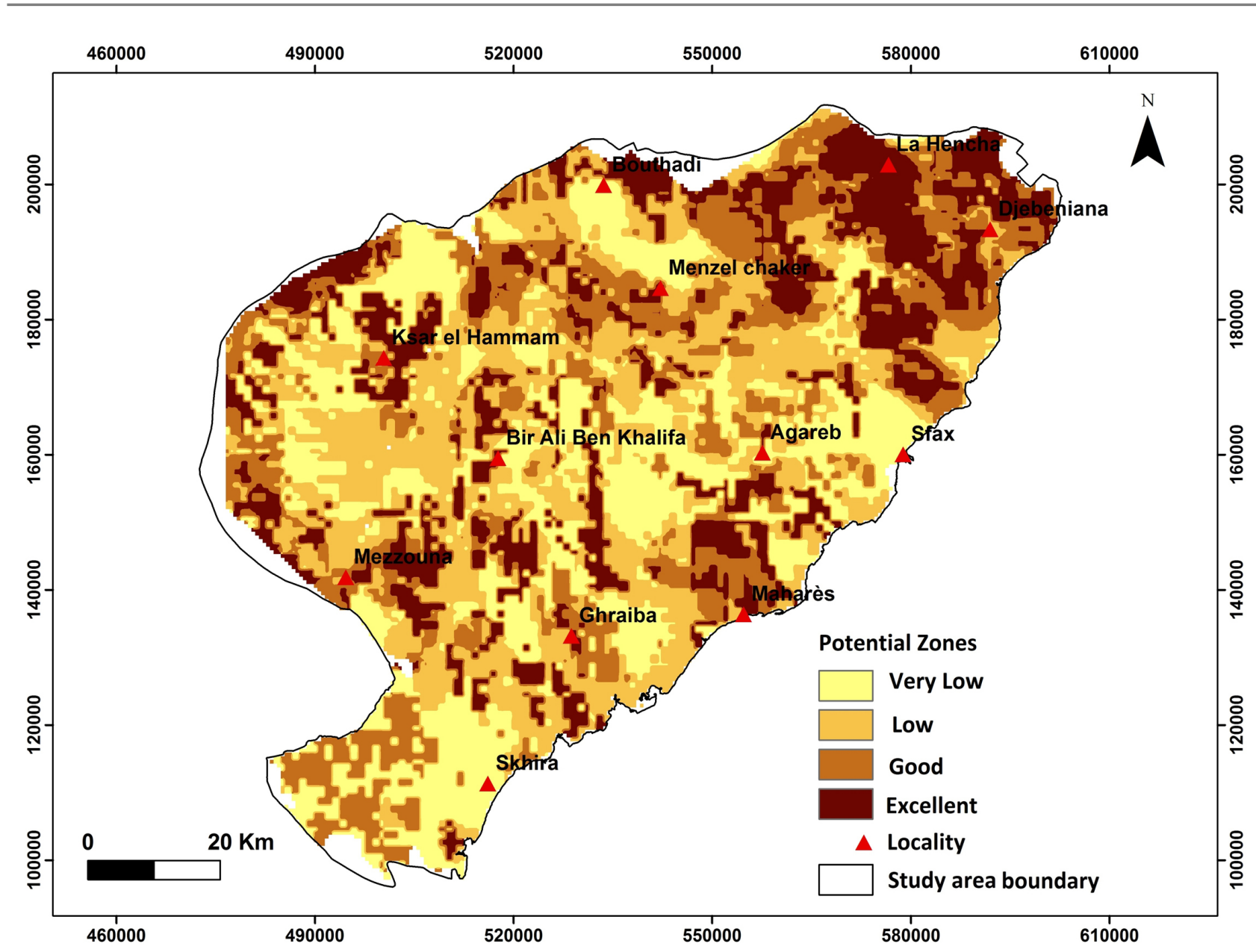

Figure 6. Groundwater potentiality map of the study area.

mostly found in the south part (Skhira) and in east particulary in Sfax region. This Areas are with low infiltration, high drainage density and steep slope.

\subsection{Results Validation}

Curve trend of sensitivity classes theory [53] was used to validate results. The groundwater potential map was validated with data on groundwater productivity relating to the aquifers in the area (4328 wells). The drilling discharge data has been classified into five classes (very strong, strong, medium, low and very low) and combined to the potentiality map. Then, for each class of the evaluation criterion, a number of pumping well is obtained which belongs to each sensitivity class of the thematic map studied (Table 3).

Trend sensitivity by sensitivity classes according to the classes of discharges have been presented. The thematic map was validated by comparing the obtained shape of the trendlines sensitivity (Figure 7) with the theoretical curves trend sensivity classes (Figure 4).

The results show that $84 \%$ of very strong discharge drillings ( $\mathrm{Q}>19 \mathrm{~m}^{3} / \mathrm{h}$ ) superimposed on the excellent and good sensitivity class; $50 \%$ drillings with low discharges $\left(1<\mathrm{Q}<2 \mathrm{~m}^{3} / \mathrm{h}\right)$ are overlapped with classes of low sensitivity. $66 \%$ of 


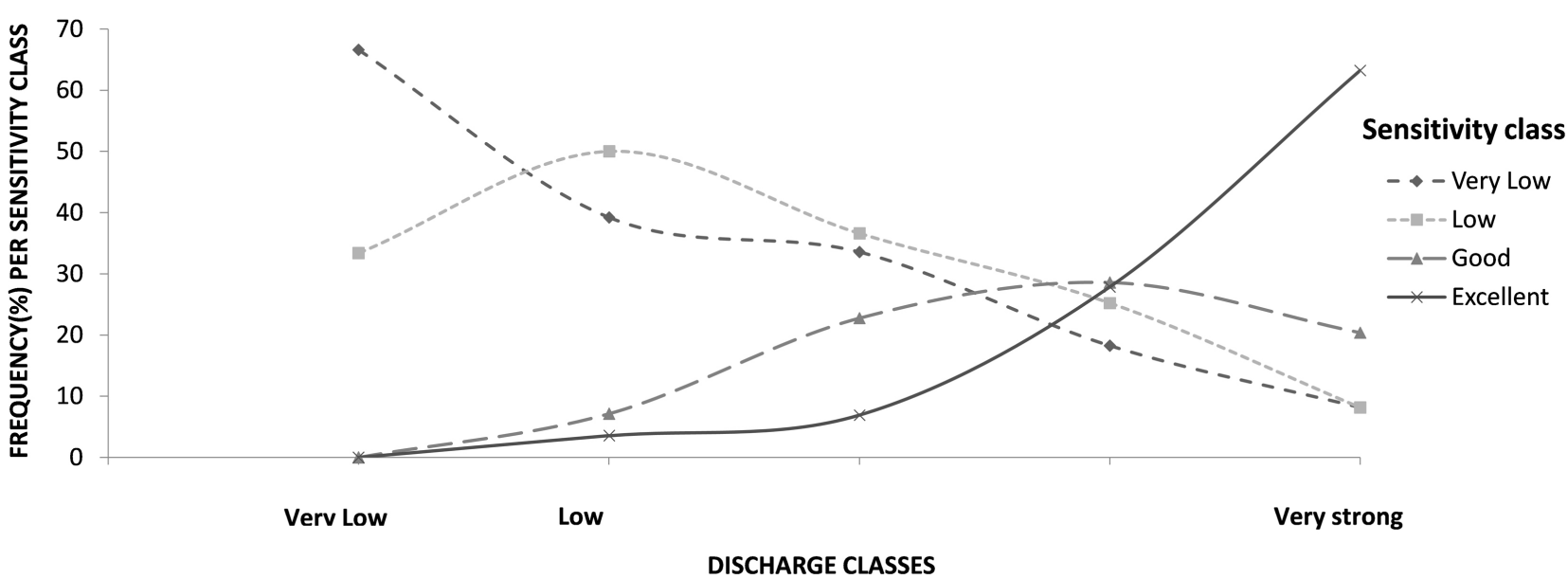

Figure 7. Results of GWPZ validation (Trend curves of the sensitivity classes).

Table 3. Percentage of discharges sensitivity classes.

\begin{tabular}{|c|c|c|c|c|}
\hline \multirow{2}{*}{ Discharge classes } & \multicolumn{4}{|c|}{ Sensitivity classes } \\
\hline & Very Low (\%) & Low (\%) & Good (\%) & Excellent (\%) \\
\hline $\begin{array}{c}\text { Very low } \\
\mathrm{Q}<1 \mathrm{~m}^{3} / \mathrm{h}\end{array}$ & 66.6 & 33.4 & 0 & 0 \\
\hline $\begin{array}{c}\text { Low } \\
1<\mathrm{Q}<2 \mathrm{~m}^{3} / \mathrm{h}\end{array}$ & 39.2 & 50 & 7.14 & 3.57 \\
\hline $\begin{array}{c}\text { Medium } \\
2<\mathrm{Q}<5 \mathrm{~m}^{3} / \mathrm{h}\end{array}$ & 33.57 & 36.6 & 22.78 & 6.95 \\
\hline $\begin{array}{c}\text { Strong } \\
5<\mathrm{Q}<19 \mathrm{~m}^{3} / \mathrm{h}\end{array}$ & 18.27 & 25.26 & 28.58 & 27.87 \\
\hline $\begin{array}{l}\text { Very strong } \\
\mathrm{Q}>19 \mathrm{~m}^{3} / \mathrm{h}\end{array}$ & 8.16 & 8.16 & 20.40 & 63.26 \\
\hline
\end{tabular}

very low $\left(\mathrm{Q}<1 \mathrm{~m}^{3} / \mathrm{h}\right)$ are superimposed on the very low sensitivity class. The excellent and good potentiality classes have high to very high productivity in the majority of cases. Also the classes of very low and low potentiality show slow productivity. The results demonstrate a good concordance between the two plots (Figure 4 and Figure 7) and the trend of excellent sensitivity class present a unimodal shape; the trend of good sensitivity class has a mode centered on the strong class of the evaluation criterion; the trend of low sensitivity class shows a Gaussian curve and the trend of the sensitivity class of the very low has unimodal shape.

\subsection{Discussion}

An overlay model was applied with six different influential parameters including infiltration rates, lineament density, drainage density, slope, rainfall and land cover/use. The AHP method was employed to determine the respective weights of the different thematic maps. The matrix analysis reveals that the infiltration 
rate, density fracturation and drainage density are the most important factors conditioning the groundwater occurrence. The model generated output shows a mirror reflection of the principal factors. High groundwater potential zones are found in high infiltration sectors, high lineament density, low drainage density, and along the nearly level area with less than $2 \%$ slope. This seems logic and confirms many results in other studies in different hydrological contexts [14] [26] [66].

Field verification was performed by comparing and superimposed the produced potentiality map and the discharge borehole data. The result shows a good agreement between the generated groundwater potential map and the pumping rates. It can be clearly seen that the majority of groundwater with high pumping rates are appeared where the qualitative results revealed good groundwater potential. This paper proves the efficacy of validation method in the alluvium environment. In fact the original method was applied for hard rock terrain [53] [67] [68].

The good results can be explained by the importance of the infiltration parameter in the estimation of the groundwater potentiality (42\%) and the accuracy of the estimation of this factor. In fact, AgriFlux model involves different data such as climatic and pedological data. The good results can also confirm the role of soil parameter in modelling water transport processing and occurrence of groundwater.

This work emphasizes the use of GIS linked model. The integration Agriflux model with geographic information system (GIS) has provided a significant contribution in the spatial data analysis and visualisation of model results. Here, the integration is done through data exchange among Arcgis-Agriflux without a common user platform. According to reference [69], this type of coupling approaches (loose coopling) are much simpler to program and may be the most realistic approaches. However, it is prone to data inconsistency, information loss, and tedious data conversion between different packages which leads to increased model setup time.

The mapping of parameters by interpolation certainly led to errors [70]. Despite this error margin in mapping, the multiparameter approach carried out by means of GIS and an AHP technique was efficient, economical and stress free work method.

In the concerned area, no maps were previously produced depending on the integration of Agriflux model, GIS and multicriteria analysis. Such map involve the main factors contributing to groundwater prospectivity in Sfax basin, especially the factors concerning the quantified groundwater infiltration rate. The developed approach has proven to be efficient, rapid and cost effective technique producing valuable results for proper groundwater resources evaluation and exploitation.

\section{Conclusions}

In this study, a methodology for demarcating groundwater potential recharge 
zonation map using a GIS-based AHP technique approach has been proposed. Multiple GIS layers were developed. Each layer was classified into different categories depending on its capability to hold groundwater. AHP is used to determine the weights of various themes. This tool appears to be a flexible decision-making and decision aiding method. The validation was performed by the use of curve trend of sensitivity classes theory. The borehole pumping data were superimposed on the groundwater potential map and numbers of wells with different yield ranges for different groundwater potential zones were evaluated.

The results indicated that recharge is controlled by many competing factors mainly infiltration rate, lineaments density and drainage density. The derived map shows groundwater potential recharge zones namely, very low, low, good, excellent which cover $26 \%, 30 \%, 21 \%$ and $23 \%$ of the study area respectively. The results demonstrate that the most effective groundwater recharge potential zones were located in the northeast and the central parts. Southern and eastern parts represent low groundwater potential sectors.

This work emphasizes the role of GIS technology in linking models. The integration Agriflux-GIS is used to quantify the groundwater flow and provide recharge estimates over large area.

The use of GIS was helpful for managing various spatial data and conducted to develop a digital database of Sfax phreatic aquifer.

The overall results reveal that integrating geographical information system (GIS), hydrology modeling and analytical hierarchy process (AHP) methods present a valuable tool for the improved prediction, monitoring and planning of water resources. This is particularly useful in developing regions, where the potential of groundwater resources is largely unknown. This work may improve our knowledge and provide additional support for groundwater management and can help planners seek suitable locations at which to implement exploration.

The approach presented in this paper can be supplemented by hydrochemical and isotopes investigations to provide more elements of knowledge of the functioning of this system. In fact, the hydrochemical analysis may complete this study and permit the development of a rational scheme for the optimal use of the Sfax aquifer.

\section{Conflicts of Interest}

The authors declare no conflicts of interest regarding the publication of this paper.

\section{References}

[1] Todd, D. and Mays, L. (2005) Groundwater Hydrology. 3rd Edition, John Wiley \& Sons Ltd., Hoboken.

[2] Mogaji, K.A., Lim, H.S. and Abdullah, K. (2014) Regional Prediction of Groundwater Potential Mapping in a Multifaceted Geology Terrain Using GIS-Based Dempster-Shafer Model. Arabian Journal of Geosciences, 8, 3235-3258. https://doi.org/10.1007/s12517-014-1391-1 
[3] Magesh, N.S., Chandrasekar, N. and Soundranayagam, J.P. (2012) Delineation of Groundwater Potential Zones in Theni District, Tamil Nadu, Using Remote Sensing, GIS and MIF Techniques. Geoscience Frontiers, 3, 189-196. https://doi.org/10.1016/j.gsf.2011.10.007

[4] Moghaddam, D., Rezaei, M., Pourghasemi, H.R., Pourtaghie, Z.S. and Pradhan, B. (2015) Groundwater Spring Potential Mapping Using Bivariate Statistical Model and GIS in the Taleghan Watershed, Iran. Arabian Journal of Geosciences, 8, 913-929. https://doi.org/10.1007/s12517-013-1161-5

[5] Anbazhagan, S. and Jothibasu, A. (2014) Modeling Water Quality Index to Assess Shallow Groundwater Quality for Sustainable Utilization in Southern India. International Journal of Advanced Geosciences, 2, 122-129. https://doi.org/10.14419/ijag.v2i2.3285

[6] Anudu, G.K., Onuba, L.N. and Ufondu, L.S. (2011) Geoelectric Sounding for Groundwater Exploration in the Crystalline Basement Terrain around Onipe and Adjoining Areas, Southwestern Nigeria. Journal of Applied Technology in Environmental Sanitation, 1, 343-354.

[7] Oseji, J.O., Atakpo, E.A. and Okolie, E.C. (2005) Geoelectric Investigation of the Aquifer Characteristics and Groundwater Potential in Kwale, Delta State, Nigeria. Journal of Applied Sciences and Environmental Management, 9, 157-160.

[8] AbdelRaouf, O. and Abdel-Galil, K. (2013) Conjunctive Use of DC Resistivity Method and Hydrochemical Analysis for Groundwater Potentiality of Wadi El Natrun Area, Egypt. International Journal of Water Resources and Arid Environments, 2, 110-119.

[9] Kuria, D.N., Gachari, M.K., Macharia, M.W. and Mungai, E. (2012) Mapping Groundwater Potential in Kitui District, Kenya. International Journal of Water Resources and Environmental Engineering, 4, 15-22. https://doi.org/10.5897/IJWREE11.119

[10] Hammouri, N.A., El-Naqa, A. and Barakat, M. (2012) An Integrated Approach to Groundwater Exploration Using Remote Sensing and Geographic Information System. Journal of Water Resource and Protection, 4, 717-724. https://doi.org/10.4236/jwarp.2012.49081

[11] Sinha, D.D., Mohapatra, S.N. and Pani, P. (2012) Mapping and Assessment of Groundwater Potential in Bilrai Watershed (Shivpuri District, M.P.) - A Geomatics Approach. Journal of the Indian Society of Remote Sensing, 40, 649-668.

https://doi.org/10.1007/s12524-011-0175-2

[12] Srivastava, P.K. and Bhattacharya, A.K. (2006) Groundwater Assessment through an Integrated Approach Using Remote Sensing, GIS and Resistivity Techniques: A Case Study from a Hard Rock Terrain. International Journal of Remote Sensing, 27, 4599-4620. https://doi.org/10.1080/01431160600554983

[13] Rajaveni, S.P., Brindha, K. and Elango, L. (2015) Geological and Geomorphological Controls on Groundwater Occurrence in a Hard Rock Region. Applied Water Science, 7, 1377-1389. https://doi.org/10.1007/s13201-015-0327-6

[14] Awawdeh, M., Obeidat, M., Al-Mohammad, M., Al Qudah, K. and Jaradat, R. (2013) Integrated GIS and Remote Sensing for Mapping Groundwater Potentiality in the Tulul al Ashaqif, Northeast Jordan. Arabian Journal of Geosciences, 7, 2377-2392. https://doi.org/10.1007/s12517-013-0964-8

[15] Al-Hanbali, A., Alsaaideh, B. and Kondoh, A. (2011) Using GIS-Based Weighted Linear Combination Analysis and Remote Sensing Techniques to Select Optimum Solid Waste Disposal Sites within Mafraq City, Jordan. Journal of Geographic Information System, 3, 267-278. https://doi.org/10.4236/jgis.2011.34023 
[16] Hentati, I., Fourati, M.A., Trabelsi, N., Triki, I., Sassi, S. and Zairi, M. (2019) Decision Support System Development to Groundwater Management and Aquifer Vulnerability Assessment: Hydrogeological Information System of Monastir (HISM). Journal of Geographic Information System, 11, 522-540. https://doi.org/10.4236/jgis.2019.115032

[17] Abd manap, M., Ramli, M., Pradhan, B. and Noraini, S. (2013) A Knowledge-Driven GIS Modeling Technique for Groundwater Potential Mapping at the Upper Langat Basin, Malaysia. Arabian Journal of Geosciences, 6, 1621-1637. https://doi.org/10.1007/s12517-011-0469-2

[18] Zende, A.M., Nagarajan, R. and Atal, K.R. (2012) Assessment of Groundwater Potential Zones by Using GIS Techniques in Yerala River Basin, Western Maharashtra, India. Journal of Advance Civil Engineering, 2, 9-17.

[19] Malekmohammadi, B., Ramezani Mehrian, M. and Jafari, H.R. (2012) Site Selection for Managed Aquifer Recharge Using Fuzzy Rules: Integrating Geographical Information System (GIS) Tools and Multi-Criteria Decision Making. Hydrogeology Journal, 20, 1393-1405. https://doi.org/10.1007/s10040-012-0869-8

[20] Abdalla, F., Moubark, K. and Abdelkareem, M. (2020) Groundwater Potential Mapping Using GIS, Linear Weighted Combination Techniques and Geochemical Processes Identification, West of the Qena Area, Upper Egypt. Journal of Taibah University for Science, 14, 1350-1362. https://doi.org/10.1080/16583655.2020.1822646

[21] Das, S. and Pardeshi, S.D. (2018) Integration of Different Influencing Factors in GIS to Delineate Groundwater Potential Areas Using IF and FR Techniques: A Study of Pravara Basin, Maharashtra, India. Applied Water Science, 8, Article No. 197. https://doi.org/10.1007/s13201-018-0848-x

[22] Saha, A., Rana, A., Tomar, S., Tripathy, S. and Singh, A. (2017) Groundwater Potential Zone Identification Using Remote Sensing and GIS Techniques-A Case Study of Karwi Block Area, Uttar Pradesh, India. Journal of Applied Geology and Geophysics, 5, 43-51.

[23] Pandian, M., Julie, M., Allwyn Fernandes, Y. and Mahammad Sartaj Basha, S.K. (2013) Resource Potential Appraisal/Assessment and to Delineate Groundwater Potential Zones in Parts of Anaimalai, Pollachi and Udumalpet Block Using Remote Sensing and GIS. International Journal of Research in Engineering and Technology, 2, 78-84

[24] Ajay Kumar, V., Mondal, N.C. and Ahmed, S. (2020) Identification of Groundwater Potential Zones Using RS, GIS and AHP Techniques: A Case Study in a Part of Deccan Volcanic Province (DVP), Maharashtra, India. Journal of the Indian Society of Remote Sensing, 48, 497-511. https://doi.org/10.1007/s12524-019-01086-3

[25] Rajasekhar, M., Sudarsana Raju, G., Sreenivasulu, Y. and Siddi Raju, R. (2019) Delineation of Groundwater Potential Zones in Semi-Arid Region of Jilledubanderu River Basin, Anantapur District, Andhra Pradesh, India Using Fuzzy Logic, AHP and Integrated Fuzzy-AHP Approaches. HydroResearch, 2, 97-108.

https://doi.org/10.1016/j.hydres.2019.11.006

[26] Elewa, H. and Qaddah, A. (2011) Groundwater Potentiality Mapping in the Sinai Peninsula, Egypt, Using Remote Sensing and GIS-Watershed-Based Modeling. $\mathrm{Hy}^{-}$ drogeology Journal, 19, 613-628. https://doi.org/10.1007/s10040-011-0703-8

[27] Ozdemir, A. (2011) GIS-Based Groundwater Spring Potential Mapping in the Sultan Mountains (Konya, Turkey) Using Frequency Ratio, Weights of Evidence and Logistic Regression Methods and Their Comparison. Journal of Hydrology, 411, 290-308. https://doi.org/10.1016/j.jhydrol.2011.10.010 
[28] Al-Abadi, A.M. (2015) Groundwater Potential Mapping at Northeastern Wasit and Missan Governorates, Iraq Using a Data-Driven Weights of Evidence Technique in Framework of GIS. Environmental Earth Sciences, 74, 1109-1124. https://doi.org/10.1007/s12665-015-4097-0

[29] Mohamed, S.E., Juanah, S.I., Wan, N.A.S. and Puziah, A.L. (2012) Groundwater Resources Assessment Using Integrated Geophysical Techniques in the Southwestern Region of Peninsular Malaysia. Arabian Journal of Geosciences, 6, 4129-4144.

[30] Oh, H.J., Kim, Y.S., Choi, J.K., Park, E. and Lee, S. (2011) GIS Mapping of Regional Probabilistic Groundwater Potential in the Area of Pohang City, Korea. Journal of Hydrology, 399, 158-172. https://doi.org/10.1016/j.jhydrol.2010.12.027

[31] Naghibi, S., Pourghasemi, H., Pourtaghi, Z. and Rezaei, A. (2014) Groundwater Qanat Potential Mapping Using Frequency Ratio and Shannon's Entropy Models in the Moghan Watershed, Iran. Earth Science Informatics, 8, 171-186. https://doi.org/10.1007/s12145-014-0145-7

[32] Razandi, Y., Pourghasemi, H., Neisani, N. and Rahmati, O. (2015) Application of Analytical Hierarchy Process, Frequency Ratio, and Certainty Factor Models for Groundwater Potential Mapping Using GIS. Earth Sciences Informatics, 8, 867-883. https://doi.org/10.1007/s12145-015-0220-8

[33] Rahmati, O., Nazari Samani, A. and Mahdavi, M. (2015) Groundwater Potential Mapping at Kurdistan Region of Iran Using Analytic Hierarchy Process and GIS. Arabian Journal of Geosciences, 8, 7059-7071. https://doi.org/10.1007/s12517-014-1668-4

[34] Al-shabeeb, A.R. (2016) The Use of AHP within GIS in Selecting Potential Sites for Water Harvesting Sites in the Azraq Basin-Jordan. Journal of Geographic Information System, 8, 73-88. https://doi.org/10.4236/jgis.2016.81008

[35] Burollet, P.F. (1956) Contribution à l'étude stratigraphique de la Tunisie centrale. Annales des Mines et de la Géologie, 18, 352.

[36] Haller, P. (1983) Structure profonde du Sahel tunisien interpretation génodynamique These 300 cycle. Univ. Besancon, Besancon.

[37] Ramaiah, S., Gopalakrishna, G., Vittala, D.S.S. and Najeeb, M. (2012) Geomorphological Mapping for Identification of Ground Water Potential Zones in Hard Rock Areas Using Geo-Spatial Information-A Case Study in Malur Taluk, Kolar District, Karnataka, India. Nature Environment and Pollution Technology, 11, 369-376.

[38] Lee, S., Kyo-Young, S., Kim, Y. and Park, I. (2012) Regional Groundwater Productivity Potential Mapping Using a Geographic Information System (GIS) Based Artificial Neural Network Model. Hydrogeology Journal, 20, 1511-1527. https://doi.org/10.1007/s10040-012-0894-7

[39] Pourghasemi, H.R., Pradhan, B., Gokceoglu, C., Mohammadi, M. and Moradi, H.R. (2013) Application of Weights-of-Evidence and Certainty Factor Models and Their Comparison in Landslide Susceptibility Mapping at Haraz Watershed, Iran. Arabian Journal of Geosciences, 6, 2351-2365. https://doi.org/10.1007/s12517-012-0532-7

[40] CRDA (2006) Commissariat Régionale de Développement Agricole, Sfax. Rapport d'analyses des éléments majeurs dans le sahel de Sfax.

[41] CRDA (2012) Commissariat Régionale de Développement Agricole, Sfax, Tunisie. Rapport annuel de l'année (2012), élaboré par Khanfir.H.

[42] Nithya, C.N., Srinivas, Y., Magesh, N.S. and Kaliraj, S. (2019) Assessment of Groundwater Potential Zones in Chittar Basin, Southern India Using GIS Based AHP Tech- 
nique. Remote Sensing Applications. Society and Environment, 15, Article ID: 100248. https://doi.org/10.1016/j.rsase.2019.100248

[43] Arulbalaji, P., Padmalal, D. and Sreelash, K. (2019) GIS and AHP Techniques Based Delineation of Groundwater Potential Zones: A Case Study from Southern Western Ghats, India. Scientific Reports, 9, Article No. 2082.

https://doi.org/10.1038/s41598-019-38567-x

[44] Doke, A.B., Zolekar, R.B., Patel, H. and Das, S. (2021) Geospatial Mapping of Groundwater Potential Zones Using Multi-Criteria Decision-Making AHP Approach in a Hard Rock Basaltic Terrain in India. Ecological Indicators, 127, Article ID: 107685. https://doi.org/10.1016/j.ecolind.2021.107685

[45] Ahmadi, H., Kaya, O.A., Babadagi, E., Savas, T. and Pekkan, E. (2021) GIS-Based Groundwater Potentiality Mapping Using AHP and FR Models in Central Antalya, Turkey. Environmental Sciences Proceedings, 5, 11. https://doi.org/10.3390/IECG2020-08741

[46] Pinto, D., Shrestha, S., Babel, M.S. and Ninsawat, S. (2017) Delineation of Groundwater Potential Zones in the Comoro Watershed, Timor Leste Using GIS, Remote Sensing and Analytic Hierarchy Process (AHP) Technique. Applied Water Science, 7, 503-519. https://doi.org/10.1007/s13201-015-0270-6

[47] Fenta, A.A., Kifle, A., Gebreyohannes, T. and Hailu, G. (2014) Spatial Analysis of Groundwater Potential Using Remote Sensing and GIS-Based Multi-Criteria Evaluation in Raya Valley, Northern Ethiopia. Hydrogeology Journal, 23, 195-206. https://doi.org/10.1007/s10040-014-1198-x

[48] Dhar, A., Sahoo, S., Mandal, U., Dey, S., Bishi, N. and Kar, A. (2015) Hydro-Environmental Assessment of a Regional Ground Water Aquifer: Hirakud Command Area (India). Environmental Earth Sciences, 73, 4165-4178. https://doi.org/10.1007/s12665-014-3703-x

[49] Saaty, T.L. (1980) The Analytic Hierarchy Process: Planning, Priority Setting, Resource Allocation. McGraw-Hill, New York.

[50] Malczewski, J. (1999) GIS and Multicriteria Decision Analysis. Wiley, New York.

[51] Al-Abadi, A.M. and Shahid, S. (2015) A Comparison between Index of Entropy and Catastrophe Theory Methods for Mapping Groundwater Potential in an Arid Region. Environmental Monitoring and Assessment, 187, 576. https://doi.org/10.1007/s10661-015-4801-2

[52] Chung, C.J.F. and Fabbri, A.G. (2003) Validation of Spatial Prediction Models for Landslide Hazard Mapping. Natural Hazards, 30, 451-472. https://doi.org/10.1023/B:NHAZ.0000007172.62651.2b

[53] Jourda, J.P., Saley, M.B., Djagoua, E.V., Kouame, K.J., Biemi, J. and Razack, M. (2006) Using Landsat ETM + Data and GIS for Assessing Groundwater Potential in the Precambrian Cracked Middle of the Korhogo Region (Northern Côte d'Ivoire): Approach Multicriteria Analysis and Test Validation. Remote Sensing, 5, 340.

[54] Larocque, M., Banton, O. and Gagnon, J. (2002) Using Models to Manage Soil Inorganic Nitrogen in Forest Tree Nurseries. Soil Science Society of America Journal, 66, 602-612. https://doi.org/10.2136/sssaj2002.6020

[55] Dupy, A. (1997) Simulation de la contamination diffuse des eaux souterraines par les nitrates à l'échelle du bassin versant. Thèse de doctorat, Université de Poitier, Poitiers.

[56] Banton, O., Larocque, M., Surateau, F. and Villeneuve, J.-P. (1993) Évaluation des pertes de composés azotés dans les eaux souterraines lors de l'épandage des fumiers et lisiers. Développement d'un outil d'évaluation-logiciel AgriFlux, manuel d'usager. 
Rapport scientifique $\mathrm{N}^{\circ} \mathrm{R}-380$, INRS-Eau, septembre 1993.

[57] Lasserre, F., Razack, M. and Banton, O. (1999) A GIS Linked Model for the Assessment of Nitrate Contamination in Groundwater. Journal of Hydrology, 224, 81-90. https://doi.org/10.1016/S0022-1694(99)00130-4

[58] Trabelsi, N., Hentati, I., Triki, I. and Zairi, M. (2019) Étude de la vulnérabilité à la pollution du système phréatique du sahel de Sfax par les outils SIG. Revue Internationale de Géomatique, 29, 317-338. https://doi.org/10.3166/rig.2019.00087

[59] Hossein, A., Ardakani, H. and Reza Ekhtesasi, M. (2016) Groundwater Potentiality through Analytic Hierarchy Process (AHP) Using Remote Sensing and Geographic Information System (GIS). Journal of Geophysics, 6, 75-88.

[60] Haridas, V.R., Aravindan, S. and Gopinath, G. (1998) Remote Sensing and Its Applications for Ground Water Favorable Area Identification. The Quarterly Journal of the Geological Association and research Centre, 6, 18-22.

[61] Saha, D., Dhar, Y.R. and Vittal, S.S. (2010) Delineation of Groundwater Development Potential Zones in Parts of Marginal Ganga Alluvial Plain in South Bihar, Eastern India. Environmental Monitor, 165, 179-191. https://doi.org/10.1007/s10661-009-0937-2

[62] Gupta, M. and Srivastava, P.K. (2010) Integrating GIS and Remote Sensing for Identification of Groundwater Potential Zones in the Hilly Terrain of Pavagarh, Gujarat, India. Water International, 35, 233-245. https://doi.org/10.1080/02508061003664419

[63] Deepika, B., Kumar, A. and Jayappa, K.S. (2013) Integration of Hydrological Factors and Demarcation of Groundwater Prospect Zones: Insights from Remote Sensing and GIS Techniques. Environmental Earth Sciences, 70, 1319-1338. https://doi.org/10.1007/s12665-013-2218-1

[64] Burrough, P.A. (1986) Principles of Geographical Information Systems for Land Resources Assessment. Oxford University Press, New York, 50.

https://doi.org/10.1080/10106048609354060

[65] Scanlon, B.R., Healy, R.W. and Cook, P.G. (2002) Choosing Appropriate Techniques for Quantifying Groundwater Recharge. Hydrogeology Journal, 10, 18-39.

https://doi.org/10.1007/s10040-001-0176-2

[66] Fashae, O.A., Tijani, M.N., Talabi, A.O. and Adedeji, O.I. (2014) Delineation of Groundwater Potential Zones in the Crystalline Basement Terrain of SW-Nigeria: An Integrated GIS and Remote Sensing Approach. Applied Water Science, 4, 19-38. https://doi.org/10.1007/s13201-013-0127-9

[67] Koudou, A., Adiaffi, B., Assoma, T.V., Sombo, A.P, Amani, E.M. and Biemi, J. (2013) Concept of a Decision-Making Tool for the Groundwater Prospecting in Hard Rock Area; Southeast of Ivory Coast. Geo-Eco-Trop, 37, 211-226.

[68] Akossi, O., Lasm, T.M., Zéphir, D.L., Kouame, F., Kouadio, E., Baka, D., Suzane, K. and Yao, F. (2014) Contribution of Remote Sensing and Geographic Information System to Identify Potential Areas of Groundwater in the Department of M'Bahiakro (Central-East of Côte d'Ivoire). Current Journal of Applied Science and Technology, 4, 2551-2575. https://doi.org/10.9734/BJAST/2014/8881

[69] Zhang, L., Desmond, O.A. and Amos, T.K.B. (2014) Integration of Geographical Information Science (GIS) Technology in Hydrological Modeling: A Critical Review. Advanced Materials Research, 838-841, 2284-2291. https://doi.org/10.4028/www.scientific.net/AMR.838-841.2284

[70] Benjmel, K., Amraoui, F., Boutaleb, S., Ouchchen, M., Tahiri, A. and Touab, A. (2020) Mapping of Groundwater Potential Zones in Crystalline Terrain Using Re- 
mote Sensing, GIS Techniques, and Multicriteria Data Analysis (Case of the Ighrem Region, Western Anti-Atlas, Morocco). Water, 12, Article No. 471.

https://doi.org/10.3390/w12020471 